\title{
Expression of Epstein-Barr virus in patients with Hodgkin's disease: report of 64 cases from Rio de Janeiro, Brazil
}

\section{Expressão do vírus Epstein-Barr em pacientes com doença de Hodgkin: relato de 64 casos do Rio de Janeiro}

Monique Morgado Loureiro'; José Carlos Morais ${ }^{2}$; Cristiane Bedran Milito; Rodrigo Doyle Portugal'; Wolmar Pulcheri'; Nelson Spector ${ }^{4}$

key words

Hodgkin's disease

Epstein-Barr virus

LMP1 abstract

Epstein-Barr virus (EBV) has been implicated in the pathogenesis of Hodgkin's disease (HD), and the association between EBV and HD is influenced by the patients' socioeconomic status, age and the presence of mixed cellularity (MC) histological subtype. The prevalence of EBV in HD varies widely. This study was undertaken to determine the prevalence of EBV in HD in a Brazilian population. We studied 64 cases with a monoclonal antibody to the EBV latent membrane protein-1 (LMP1). EBV was detected in 35 of the 64 cases (55\%) and its presence was significantly correlated with the MC subtype (OR $=9 ;$ IC $95 \%=1.66-66 ; p=0,0015)$. These results support that EBV is related to HD in a Brazilian population. resumo

O vírus Epstein-Barr (EBV) tem sido implicado na fisiopatogenia da doença de Hodgkin (DH) e a associação deste vírus com a DH está relacionada com as condições socioeconômicas da população estudada, com a idade e com o subtipo histológico celularidade mista (CM). A prevalência do EBV na DH é muito variável. Este estudo foi realizado com o objetivo de determinar a prevalência do EBV na DH em uma população brasileira. Foram estudados 64 casos de DH oriundos do Hospital Universitário utilizando-se o método de imunoistoquímica com anticorpo monoclonal contra a proteína latente da membrana (LMP1). O vírus foi encontrado em 35 dos 64 casos estudados (55\%) e sua presença correlacionou-se de maneira significativa com o subtipo histológico $C M(O R=9 ; I C 95 \%=1,66-66 ; p=0,0015)$. Estes resultados confirmam que o EBV está relacionado com a DH em uma população brasileira. unitermos

Doença de Hodgkin

Virus Epstein-Barr

LMP1

1. Assistant professor; Hematology Service, Faculdade de Medicina and Hospital Universitário of Universidade Federal do Rio de Janeiro (UFR)).

2. Associate professor; Pathology Department, Hospital Universitário of UFRI.

3. Assistant professor; Pathology Department, Hospital Universitário of UFR].

4. Associate professor; Hematology Service, Faculdade de Medicina and Hospital Universitário of UFRI.

The paper is based on a master dissertation by dr. Monique Morgado Loureiro, supervised by dr. Nelson Spector and dr. José Carlos Morais, entitled Prevalência do Vírus Epstein-Barr em Pacientes com Doença de Hodgkin Acompanhados no Hospital Universitário Clementino Fraga Filho; 2000, Postgraduate Program in Internal Medicine, Universidade Federal do Rio de Janeiro, Brazil.

The work was partially funded by Capes and CNPq. 


\section{Introduction}

The role of Epstein-Barr virus (EBV) in the pathogenesis of Hodgkin's disease has been intensely debated during the last three decades. There are a number of epidemiological evidences that suggest an etiologic role for EBV in Hodgkin's disease, and it is of substantial interest that the prevalence of EBV in Hodgkin's disease varies sharply worldwide. EBV was detected in $100 \%$ of patients with HD in countries such as Honduras ${ }^{(2)}$ and Peru ${ }^{(6)}$, but in less than $50 \%$ of HD cases in the United Kingdom ${ }^{(14)}$, the United States ${ }^{(3)}$ and Costa Rica ${ }^{(9)}$.

Prevalence in Brazil can be as high as $79 \%$ in children from the state of Ceará(1). However, geographic differences strongly influence distribution of age and of the histologic subtypes ${ }^{(10)}$.

\section{Objective}

We undertook this study in order to determine the prevalence of EBV in patients with HD from the state of Rio de Janeiro.

\section{Methods}

A full review of the pathological archive of Hospital Universitário/Universidade Federal do Rio de Janeiro since its inception in 1979 until 1996 identified 119 cases of Hodgkin's disease. Fifty-five cases had to be excluded from the analysis because the paraffin blocks were unavailable. The remainder 64 cases, forming the study group, were revised by an experienced hemopathologist and classified according to the Rye classification ${ }^{(8)}$.

Immunohistochemical studies for EBV latent membrane protein-1 (LMP1) were performed using the CS1-4 antibody cocktail (Dako), at a dilution of 1:50. The following clinical variables were also recorded: age, sex, clinical stage (Ann Arbor) and performance status (ECOG).

Proportions were compared with the Yates-corrected chi-square test and Fisher's test, when appropriate.

\section{Results}

\section{Clinical characteristics and histologic features}

The median age was 37 years (range, 11-84 years). In two patients, the histological classification was not possible. The clinical and histological features are shown in Table 1.

\section{Immunohistochemical findings}

Expression of LMP1 was identified in the cytoplasm and membrane of the Hodgkin's cells and variants. Overall, EBV was identified in 35 cases (55\%). The prevalence rate of EBV in the different histologic subtypes is shown in Table 2.

EBV was present in $63 \%$ of male patients but in only $38 \%$ of female patients. The EBV was identified in $61 \%$ of patients with advanced clinical stage (III and IV) and in 50\% of patients with early stages.

EBV was detected in $75 \%$ of patients younger than 18 years and in $52 \%$ of older patients, but this difference was not significant.

It is noteworthy that the presence of EBV correlates significantly with the mixed cellularity subtype $(\mathrm{OR}=9$; IC $95 \%=1.66-66 ; p=0,0015)$, but not with sex, age and clinical stage.

\section{Discussion}

The study of the epidemiology of Hodgkin's disease has suggested the existence of different patterns of disease according to the level of industrial and socioeconomic development of the countries. Poor countries are characterized by a lower incidence of Hodgkin's disease, an absence of the incidence peak in the third decade of life, and a predominance of the mixed cellularity subtype over nodular sclerosis. In contrast, the pattern in rich countries includes an increased incidence in females, a third decade peak and a predominance of the nodular sclerosis subtype ${ }^{(7)}$.

The data from Brazil appear to corroborate this model. Brazil's poorest region, the northeast, still reveals a predominance of mixed cellularity cases ${ }^{(11)}$, while in a series from Campinas, in Brazil's richest state of São Paulo, 78\% of patients had nodular sclerosis ${ }^{(13)}$. In the present series, from Rio de Janeiro, $55 \%$ of the patients had nodular sclerosis.

Another salient feature in the data from Brazil is the very high prevalence of advanced disease at diagnosis. In the present series $78 \%$ had advanced disease, and in Campinas $68 \%$ had advanced disease. This is likely the result of delayed diagnosis, due to the shortcomings of the public health system. We have previously reported that the median time elapsed from the beginning of symptoms to 


\section{Clinical and histological features of}

Table 1 the 64 patients with Hodgkin's disease

\begin{tabular}{lc}
\hline Clinical features & Patients \\
Sex & \\
Male & $43 / 64(67 \%)$ \\
Female & $21 / 64(33 \%)$ \\
Ann Arbor stage & \\
Early (I-II) & $10 / 46(22 \%)$ \\
Advanced (III-IV) & $36 / 46(78 \%)$ \\
Histologic subtype & \\
Nodular sclerosis & $35 / 64(55 \%)$ \\
Mixed cellularity & $16 / 64(25 \%)$ \\
Lymphocyte depletion & $7 / 64(11 \%)$ \\
Lymphocyte predominance & $4 / 64(6 \%)$ \\
Unknown & $2 / 64(3 \%)$ \\
B symptoms & $46 / 62(74 \%)$ \\
PS (ECoG) & \\
0 & $47 / 62(76 \%)$ \\
1 & $7 / 62(11 \%)$ \\
2 & $3 / 62(5 \%)$ \\
3 & $2 / 62(3 \%)$ \\
4 & $3 / 62(5 \%)$ \\
Localization & \\
Cervical & $46 / 62(74 \%)$ \\
Supraclavicular & $27 / 62(43 \%)$ \\
Axillary & $25 / 62(40 \%)$ \\
Retroperitoneal & $25 / 62(40 \%)$ \\
Inguinal & $16 / 62(26 \%)$ \\
Mediastinal & $16 / 62(26 \%)$ \\
Hepatomegaly & $15 / 62(24 \%)$ \\
Splenomegaly & $23 / 62(37 \%)$ \\
\hline & \\
& \\
\hline &
\end{tabular}

the diagnosis of Hodgkin's disease was five months (range, $1-36$ months)(12).

With regard to EBV, the overall prevalence is strongly influenced by the rate of the mixed cellularity subtype in a given population. The rates of EBV positivity are consistently high in this subtype, ranging from $88 \%$ in the present series to $93 \%$ in Campinas and to $100 \%$ in the northeast. Such rates, not seen in the other subtypes of Hodgkin's disease, suggest that EBV might be directly implicated in the pathogenesis of this disease subtype.

The case for a role of EBV in the pathogenesis of Hodgkin's disease has become stronger as new evidence has linked EBV to the NF- $\kappa B$ transcription factor. It has been demonstrated that EBV's LMP1 is a constitutively aggregated pseudo-tumor necrosis factor receptor that directly activates $\mathrm{NF}-\mathrm{KB}^{\left({ }^{(4)}\right.}$. Moreover, it has been shown that NF- $\mathrm{KB}$ activity is essential in the growth and survival of lymphoblastoid cell lines transformed by EBV, and that NF- $\kappa B$ inhibition induces apoptosis of these cell lines ${ }^{(5)}$.

\section{Conclusion}

In this study the prevalence of de EBV in HD was $55 \%$ and it was higher in the histologic group of MC in a Brazilian population. A comprehensive panorama of the features of Hodgkin's disease in a country so diverse in its ethnicity and sociology as Brazil might help us better understand the complex interplay between biological and environmental factors that appears to lie at the very core of the pathogenesis of Hodgkin's disease.

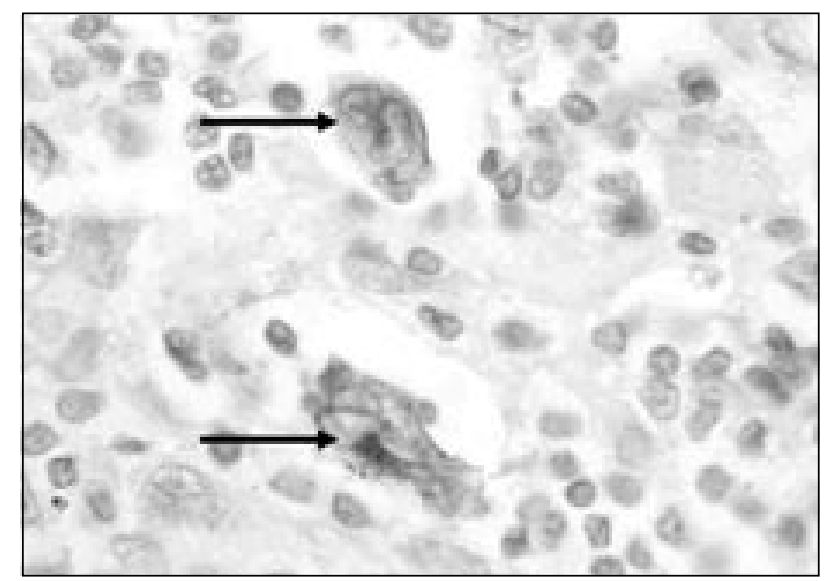

Figure - Two Reed-Sternberg cells with positive markings for EBV (arrows). The upper one has a membrane marking, and the bottom one, a membrane marking and a Colgi-placed dot

\section{Table 2 Prevalence rate of $\mathrm{EBV}$ in the histologic subtypes}

$\begin{array}{lcc}\text { Histologic subtype } & \text { LMP1 positivity } & \text { Frequency } \\ \text { Nodular sclerosis } & 14 / 35 & 40 \% \\ \text { Mixed cellularity } & 14 / 16 & 88 \% \\ \text { Lymphocyte depletion } & 4 / 7 & 57 \% \\ \text { Lymphocyte predominance } & 2 / 4 & 50 \%\end{array}$




\section{References}

I. ABREU, E. S.; FERREIRA, F. V. A.; ROCHA FILHO, F. D. et al. Doença de Hodgkin infanto-juvenil no estado do Ceará e sua relação com o vírus Epstein-Barr: parâmetros clínicos e análises morfológicas, imunoistoquímica e por hibridização in situ.J Bras Patol, v. 33, p. 178-84, 1997.

2. AMBINDER, R. F.; BOWNING, P. F.; LORENZANA, l. et al. Epstein-Barr virus and childhood Hodgkin's disease in Honduras and the United States. Blood, v. 81, p. 462-7, 1993.

3. ANDRIKO, J. A.; AGUILERA, N. S.; NANDEDKAR, M. A. et al. Childhood Hodgkin's disease in the United States: an analysis of histologic subtypes and association with Epstein-Barr virus. Mod Pathol, v. I0, p. 366-7I, 1997.

4. CAHIR-McFARLAND, E. D.; IZUMI, K. M.; MOSIALOS, G. Epstein-Barr virus transformation: involvement of latent membrane protein I-mediated activation of NF-kappaB. Oncogene, v. 18, p. 6959-64, 1999.

5. CAHIR-McFARLAND, E. D.; DAVIDSON, D. M.; SCHAUER, S. L. et al. NF-kB inhibition causes spontaneous apoptosis in Epstein-Barr virus-transformed lymphoblastoid cells. Proc Natl Acad Sci USA, v. 97, p. 6055-60, 2000.

6. CHANG, K. L.; ALBUJAR, P. F;; CHEN,Y.Y. et al. High prevalence of Epstein-Barr virus in Reed-Sternberg cells of Hodgkin's disease occurring in Peru. Blood, v. 81, p. 496-501, 1993.

7. CORREA, P.; O'CONNOR, G. T. Epidemiologic patterns of Hodgkin's disease. Int J Cancer, v. 8, p. 192-201, 1971.
8. LUKES, R. J.; CRAVER, L. F.; HALL, T. C. et al. Report of the Nomenclature Committee. Cancer Res, v. 26, p. I31 I, 1966.

9. MONTERROSO,V.; ZHOU,Y.; KOO, S. et al. Hodgkin's disease in Costa Rica: a report of 40 cases analyzed for Epstein-Barr virus. Am J Clin Pathol, v. 109, p. 6I 8-24, 1998.

10. OLIVEIRA, E. D.; BACCHI, M. M.; ABREU, E. S. et al. Hodgkin's disease in adult and juvenile groups from two different geographic regions in Brazil: characterization of clinicopathologic aspects and relationship with Epstein-Barr virus infection. Am J Clin Pathol, v. I I8, p. 25-30, 2002.

I I. PITOMBEIRA, M. S.; FERREIRA, F. V.; MARTINS, J. M. Doença de Hodgkin-I. Perfil histopatológico no estado do Ceará. Rev Med Fed Ceará, v. XXII, p. 19-28, 1981.

12. SPECTOR, N.; COSTA, M. A.; PULCHERI, W. et al. C-MOPP/ABV yields good results in a public hospital population with Hodgkin's disease in Brazil. Cancer, v. 7I, p. 2823-7, 1993.

I 3.VASSALO, J:; METZE, K.;TRAINA, F. et al. Expression of EpsteinBarr virus in classical Hodgkin's lymphomas in Brazilian adult patients. Haematologica, v. 86, p. 1227-8, 2001.

14. WEINREB, M.; DAY, P. J.; MURRAY, P. G. et al. Epstein-Barr virus and Hodgkin's disease in children: incidence of EBV latent membrane protein in malignant cells. J Pathol, v. I68, p. 365-9, 1992. 